\title{
Constructing Contemporary Nationhood in the Museums and Heritage Centres of Catalonia
}

Colin Breen*, Wes Forsythe**, John Raven***

\begin{abstract}
Geographically, Spain consists of a complex mosaic of cultural identities and regional aspirations for varying degrees of autonomy and independence. Following the end of violent conflict in the Basque country, Catalonia has emerged as the most vocal region pursuing independence from the central Spanish state. Within the Catalan separatist movement, cultural heritage sites and objects have been appropriated to play an intrinsic role in supporting political aims, with a variety of cultural institutions and state-sponsored monumentality playing an active part in the formation and dissemination of particular identity-based narratives. These are centred around the themes of a separate and culturally distinct Catalan nation which has been subject to extended periods of oppression by the varying manifestations of the Spanish state. This study addresses the increasing use of museums and heritage institutions to support the concept of a separate and distinctive Catalan nation over the past decade. At various levels, from the subtle to the blatant, heritage institutions are propagating a message of cultural difference and past injustice against the Catalan people, and perform a more consciously active, overt and supportive role in the independence movement.
\end{abstract}

Key words: Catalonia, museums, heritage, identity, nationhood

Across contemporary Europe a range of nationalist and separatist movements are again gaining momentum (Borgen 2010). From calls for independence in Scotland and the divisive politics of the Flemish and Walloon communities in Belgium, to the continually complicated political mosaic of the Balkan states, there are now a myriad of movements striving for either greater or full autonomy for their region or peoples. Across Spain there is a similar range of nationalist and regionalist movements ranging from the previously violent campaign waged in the Basque region to the 'softer' campaign for nationhood recognition for the Canary Islands (Conversi 2000; Gillespie 2015; Humlebaek 2015). Catalonia, an autonomous region in the northeast of the Iberian Peninsula bordering the Mediterranean, has seen the emergence of probably the most vocal and visible separatist movement in the country. While historically this movement was associated with calls for greater autonomy for the region and increased recognition of a separate Catalan 'nation' within a federal state, recent years have seen a more sustained campaign for full independence. This shift is supported by the main centrist political groupings within the region and is reflected in the increased politicization of cultural institutions and publicly supported events and activities. In particular, this paper addresses the increasing use of museums and heritage institutions to support the concept of a separate and distinctive Catalan nation. At various levels, from the subtle to the blatant, heritage institutions are propagating a message of cultural difference and perceived past injustice against the Catalan people and places.

From a methodological perspective the study examined the presented narratives at these centres through the use of critical discourse analysis and associated qualitative survey, to understand the frames of knowledge and power associated with their development. The study adopted Smith's (2015: 459) conceptual framework which argues that many visitors to a museum or heritage centre are engaged in a form of 'cultural performance', where they are 
'either consciously or unconsciously seeking to have their views, sense of self, and social or cultural belonging reinforced'. She has further argued that heritage as such is not necessarily about materiality, but instead a 'subjective political negotiation', centred around identity, memory and place. Research was focussed on Barcelona as part of a wider political geography research project on the cultural and heritage aspects of separatism over the past decade, with the Catalonia History Museum, Barcelona City History Museum, El Born Cultural Centre, the Maritime Museum at the Royal Shipyards and Montjuïc Castle receiving particular attention. In the broader context of Catalan heritage institutions, a number of these were established relatively recently. The Catalonia History Museum moved to its current premises in the Port in 1992, while the El Born Centre was opened in 2013. Exhibitions at Montjuïc are constantly changing, and are reflective of shifting themes and ideas around the past use of the site. It is apparent that each of these places has focussed on two primary audiences, internal Catalan visitors and external European tourists, as evidenced by the translated text presented. Within the displays and exhibits, Catalan is the primary language used, with a supporting Spanish text, and is usually accompanied by an English translation and occasional further European languages.

Findings suggest that a number of common themes structured around cultural distinctiveness and political oppression are central to the presented narratives of these centres, and that their exhibits explicitly promote a cultural Catalan nation.

\section{Heritage and Nationhood}

The theologian Adrian Hastings has argued that it was during the nineteenth century that the concept of a nation being bounded by a state emerged (Hastings 1997). Such a state would have its own borders, often structured to protect against perceived external threats. These nations were primarily defined by a common, or shared set of cultural traditions, and bound by a common language. In examining this concept of a national or group identity Hobsbawn and Ranger suggested that such an identity emerges from a collective inheritance that may develop over many millennia (Hobsbawm and Ranger 1983). Such an inheritance may have a considerable antiquity but can also be subject to continual fluidity and change and should not be viewed as a static, unchanging entity. It is also recognised that history and heritage can often be manipulated to create, confirm and reaffirm this collective identity. Individuals and movements within contemporary national states have then tried to maintain and negotiate this identity set through interpretation and activities based around aspects of their built environment, art and culture, and to further interpret it through museums, monuments and other forms of remembrance. Tunbridge and Ashworth (1996) wrote that 'the present selects an inheritance from an imagined past for current use and decides what should be passed on to an imagined future'. Social or political actors can then reimagine a past in terms that benefit their perspective and preferred direction. Benedict Anderson saw this engagement with heritage as one of the connectors of his 'imagined community' with nationhood (Anderson 1983). In many countries the heritage industry has been enrolled as a means with which to disseminate narratives of nationalism to targeted popular audiences (Wright 1985). One of the primary vehicles for the dissemination of these messages has been museums. The heritage and museum specialist Fiona McLean has shown that these institutions play an active role in the negotiation and construction of national identities (McLean 1998). For example, Armanda Scorrano (2012) argued that museums continue to be instrumental in the evolution of Australian national identities, although there is increasing awareness about the degree to which a museum can be objective (Hein 2014). On a global scale, museums themselves are changing and increasingly representing the multi-vocality and cultural complexity of contemporary societies, but many national and regional museums continue, either consciously or subconsciously, to shape and reflect national consciousness and aspiration.

Museum geographers discuss museums as centres for the examination of identity, but can also explore dissonant histories, or are places of resistance and centres that focus on the post-colonial gaze (Phillips et al. 2015). Museum narratives are then a form of storytelling, and an analysis of their discourses can help us understand the underlying political and social relationships that developed around these stories (Ryan et al. 2016). Such an exploration of 
museum and heritage centres in Barcelona can help us better understand the foundations for the separatist discourse that has developed in Catalonia over the past two decades.

\section{Heritage institutions and identity in Catalonia}

Across nineteenth-century Europe a series of nationalist movements emerged, dominated for the most part by the intelligentsia and cultural elite. A similar movement emerged in Catalonia, centred around a group of writers, poets and academics. Members of the cultural movements of the mid nineteenth-century Renaixença and the early twentieth-century Noucentisme were interested in creating a Catalan renaissance through the propagation and celebration of Catalan heritage, culture and language, and a desire to highlight the cultural separateness of Catalonia from the rest of Spain (Gracia Alonso 2013). Barcelona was central to this; and nationalist politicians and town planners from the turn of the century deliberately set out to recreate what was one of the great world cities as an effective capital for the region, and as the new 'Paris of the South' (Monclús 2000). Ambitious plans were adopted to create a new sense of monumentality, centred on great buildings, and a plan was formulated to develop the Gothic Quarter, to immediately link the city back to the capital of the Kingdom of Aragon in the Middle Ages. This transformation of the urban space, manipulated through the conservation, restoration and creation of historic looking facades, was deliberately designed to create a vista of antiquity that would link Catalonia's powerful and independent past to an ambitious, successful and independent future. A further central strategy was the establishment of Catalan cultural institutions, leading to the establishment of the Junta de Museus (Museum's Board) by the city council in $1907 .{ }^{1}$ Following the establishment of a form of autonomous government in the region in 1914, the Mancomunitat, the Board became more formalised and relevant. These initial movements towards separatism were viewed as a threat by the military, which in 1923 undertook a coup with the support of the monarchy and established a quasi-dictatorship under General Primo de Rivera (1923-30). The General disbanded Catalan institutions and altered cultural policy and activities to demonstrate the supremacy and cultural centrality of Spanish nationalism (Laitin 1989). Central to this was the organisation of the Exposición Internacional in Barcelona in 1929, designed to showcase the advanced industrial economy of the region and to showcase its landscape. Attempts to highlight the distinctiveness of Catalan identity were side-lined by the government in Madrid but an elaborate cultural complex was established at the Palacio Nacional at Montjuïc (Mackay 1985). Two years later the Spanish Republic was declared in Madrid and the Catalan Republic was announced in the same year, within the Spanish entity. The autonomous government of Catalonia, the Generalitat, established the Museu d'Art de Catalunya (Museum of Art of Catalonia) in 1934 and the Museu d'Archeòlogia (Archaeology Museum) in 1935, both within pavilions that had been constructed for the 1929 Exhibition.

Following the descent of Spain into Civil War and the emergence of Franco's nationalist dictatorship after 1939, the regime advocated a conservative centralist ideology that sought to deconstruct the cultural regionalism of early twentieth-century Spain. Museums that had been closed during the war period were now reopened, including the Archaeological Museum of Barcelona, the Archaeological Museum of Girona, the Art Museum of Barcelona and the Palaeo-Christian Museum of Tarragona. While the content and interpretative frameworks of the museums changed little in the ensuing years, it has been suggested that the reopenings were effectively presented as 'inaugurations' of new institutions that were reflective of the new, benevolent regime (De Lluc Serra and Alcalde 2016). It is only the maritime museum, first opened in its current building in 1936, with its overt emphasis on the maritime world of Spain, that could be considered as conforming to Franco's concept of a singular, one nation Spain. With the death of Franco in 1975, Spain began the process of democratization and a recognition of diversity. A new Constitution in 1978 divided the country into seventeen regions, while Article 2 of the document guaranteed the right to autonomy of the nationalities and regions within the country (Guibernau 1997). In the following year the 1979 Catalan Statute of Autonomy referred to Catalonia as a 'nationality', and built on the Separatist cause that alludes to the existence of a separate Catalan state originating in the medieval period. It further included a statement pertaining to Catalans recovering their right to self-governance. 
Museums responded in a similar manner: Holo has documented the shift in cultural institutions away from the homogenous concept of a single unified cultural state under Franco towards the recognition of plurality in newly democratized Spain (Holo 1999). Significantly, each of the new comunidades autónomas or autonomous regions took over responsibility for most museums and heritage institutions. Other facets of Catalonia's cultural fabric responded in similar ways. Dorothy Noyes (2003) has documented how activists in the immediate post-Franco period used the Patum, a festival held at Berga during Corpus Christi that had previously been used as a tool of resistance against the regime, to promote reconciliation and compromise. Through the use of effigies, masked figures and other elements the centuries old festival was used to make 'Catalans feel Catalan', in opposition to Franco, and now as a mediating tool to reflect the openness and willingness of Catalonia to move forward. Testa (2014) has further argued that while traditional festivals played a similar role during the transition to democracy, their appropriation by the Catalan independence movement has led to polarization between Catalan and Spanish parties. Sánchez-Carretero (2012) has written on the fractures that emerge during the patrimonialization process, issues of the social construction of heritage, and the issues around local social actors appropriating heritage for their own purposes.

As regionalism took hold, the centrality of heritage in promoting separateness again came to the forefront in Catalonia. The dominant Catalan electoral alliance from the 1980s, $\mathrm{CiU}$ (Convergence and Union), has consistently used history as a tool to differentiate Catalonia from the rest of Spain. Jordi Pujol, President of Catalonia's Generalitat (1980-2003) has repeatedly made reference to the importance of Catalan culture and language in his speeches and writings (Pujol 1979). The alliance's tendency was to orientate itself politically northwards, reminiscent of the geopolitics of the Middle Ages and away from 'Moorish' Spain. Pujol makes repeated reference to the flourishing of industry and cultural activity across Catalonia from the middle of the eighteenth century onwards, in comparison to the slow decline and agrarian economy of Spain. Interestingly, this narrative becomes somewhat entangled in a number of the local interpretations of Catalonia from the eighteenth century onwards. Interpretative heritage displays at centres like the regional government-supported El Born Cultural Centre in Barcelona repeatedly refer to the loss of Catalan liberty and the effective collapse of its culture following the 1714 fall of the city.

The regional government continues to support a number of museums across Catalonia including archaeological museums in Girona, Tarragona and Barcelona, (managed by the Catalan Agency for Cultural Heritage under the Department of Culture) as well as a number of heritage and cultural centres. In a highly significant move the Generalitat created the Museum of History of Catalonia (Museu d'Història de Catalunya: MHC) in 1996. In many ways this was envisaged as a non-traditional museum without its own collections. According to its mission statement, it was designed as a place 'to conserve, exhibit and make known the history of Catalonia as a collective heritage and to strengthen the Citizens'. The museum is divided into two galleries, one predating and the other post-dating 1714 . The first focusses on the development of human settlement in Catalonia from the earliest settlers onwards, but predominantly explores the development and flourishing of Catalan culture in the medieval period, when Barcelona is interpreted as one of the great capitals of the Mediterranean world. The second gallery is largely divided between showing how Catalan culture struggled through to the present, especially during the Franco period, and illustrates the contributions of Catalans to world industry. Throughout, although not glossing over specific periods of persecution, the interpretation is keen to demonstrate that Catalan culture has always been multi-cultural and socially progressive. It utilizes what was then cutting edge technology - moving video imagery of individuals and recordings of major moments in Catalonia's recent political history - but which now seems dated - to project la memòria d'un país, or 'the memory of a country'. A final multi-media exhibit at the end of the gallery, labelled a 'Portrait of Contemporary Catalonia', attempts to show the region as vibrant, culturally mixed and progressive. It uses a series of video-projected talking heads, drawn from a diverse demographic, that speak with pride about the pluralized and European orientated Catalan state.

Aside from museums and cultural institutions, the regional government in Catalonia has invested in the designation and promotion of world heritage sites in the region. To date nine sites have received World Heritage status including prehistoric rock art sites, the Roman 
period settlement site at Tarraco, the medieval monastery at Poblet founded in 1150 and the distinctive modern architecture associated with the architect Antoni Gaudi (1852-1926), as well as Palau de la Música Catalana. In the Pyrénées, the Boí Valley with its dramatic scenery and complex of Romanesque churches was inscribed on the list in 2000. Aspects of the region's intangible heritage has also been inscribed, including the festival and performances associated with the annual Patum de Burga, as has the region's Mediterranean diet and its distinctive human towers or Castells, inscribed in 2010. Landers suggests that both the government's approach and that of the region's tourism body, Turisme de Catalunya, utilize these sites to project Catalonia as a place with an ancient and autonomous past, occupied by a distinct cultural group, as part of the process of nation building (Landers 2010).

Façadism and the recreation of historic streetscapes has been well attested to as a cultural practice linked to the building of a nation (Orbasli 2002), and the authorities in Barcelona have engaged heavily in this practice at various times over the last two centuries. Most notably the central Cathedral Quarter was extensively refurbished, or created to a certain extent, on a number of occasions during the past two centuries to make it look more 'authentically' medieval, and to create the sense that Barcelona is one of the major historic European cities alongside Rome or Paris. In the 1860s a gothic façade was added to the cathedral and the project was finished in the opening decade of the twentieth century when a spire was added (Ganau 2008; Garcia-Fuentes 2015). An associated plan to transform the area in front of the cathedral into a great square containing the city's administrative centre was mooted at the same time. Gradually over the next decades the space was transformed to represent a medieval square and historic centre of the city using traces of existing buildings and architectural fragments imported into the site from other parts of old Barcelona. A complex project to create a gothic quarter was also undertaken, with architectural measures to create a uniform neo-medieval quarter through the refurbishment, selective demolition and retention of buildings and streetscapes across this area (Gant 2014). During the course of the work on the old urban centre numerous sites of archaeological interest were uncovered. The Roman period received particular attention. In a further move to reinforce the city's long historical importance, a modern interpretative centre has been built around a Roman period streetscape, exposed during mid twentieth-century archaeological excavations, at one of the centres of the Barcelona City History Museum (Museu d'Història de Barcelona) at Plaça del Rei.

In tandem with this recreation and fetishization of the antique through the selective reconstruction and retention of historic building fabric, other forms of heritage and monumentality have also been used to memorialize the concept of a Catalan state. In 1980, 11 September was decreed the national holiday of Catalonia, 'The Diada', by the regional government to commemorate the date of the fall of Barcelona in 1714. In a highly symbolic act, for the opening event on the Diada Nacional de Catalunya, the city leaders and other institutions lay wreathes of commemoration at the Rafael Casanova I Comes monument, by the sculptor Rossend Nobas, in central Barcelona. This first took place in 1913. Traditionally, Casanova is remembered as the leader of the Barcelona army besieged by the Bourbon army in 1714 during the War of Succession (Crameri 2011). The statue was originally commissioned in 1886, at the same time as the cathedral and Gothic Quarter were receiving attention, for erection on the avenue leading to the demolished eighteenth-century citadel. This fortification was widely seen as a physical expression of Bourbon oppression. The statue was later moved in 1914, marking the bicentenary of 1714 , to Ronda de Sant Pere where Casanova was believed to have been wounded during the siege. During the Franco regime it was removed, but was again erected after 1977 following the dictator's death. 1714 features large in the city's use of memorial space. The Fossar de les Moreres, next to the cathedral of Santa Maria del Mar, was constructed in 1988 to commemorate the events of 1714 (Hallal 2006). This memorial square, designed as a public space, was built over the location where the defenders killed during the siege were supposedly buried. An inscription on the granite bench defining the space reads In the cemetery of the Moreres there has not been buried a single traitor; even if we lose our flags it will be the urn of their honour: To the martyrs of 1714. Additionally, an eternal flame on a curved steel sculpture adorns the centre of the area. Along with the Casanova statue, this site of memory plays a significant role in annual Diada events and has come to represent an area considered central to Catalan remembrance. While the Casanova statue attracts official 
acts of remembrance, the plaza has come to be increasingly associated with leftist and activist groups engaged in their own commemorative activities.

In 1919 Josep Puig i Cadafalch was commissioned to erect four columns at Montjuïc to represent the four stripes of the Catalan senyera, or national flag. Removed in 1928 during Primo de Rivera's reign, they were replicated in the Plaça d'Espanya in 2010, marking the highly visible entrance to the national gallery and overlooking the large public space below. More recently the 1991 Monument to Francesc Macià, by Josep Maria Subirachs was erected in memory of the Catalan President Francesc Macià ${ }^{2}$ and his role in the State. The largely concrete structure erected in the Playa de Cataluyna portrays an upside-down staircase symbolizing the gradual construction of the Catalonian state. Finally, a monument to the memory of Lluís Companys i Jover, president of Catalonia from 1934, was erected in 1998 by Francisco López Hernández near the Arc de Triomf. It carries the inscription Catalonia and freedom are the same thing: where freedom lives, there my homeland is. It includes a statue to Conxita Julià i Farrés, poet and friend to Companys, immortalized by the handkerchief given to her by the president, and now on display in the Catalonia History Museum.

At each of these places a number of common themes emerge. As with the World Heritage process many of the displays and exhibits are concerned with the distinctiveness of Catalan culture and with its antiquity outside of the sphere of the rest of the lberian Peninsula. Indeed, there is a strong narrative emphasizing Catalonia's place in the Mediterranean world and its progressive place in culture, philosophy and politics, with references to Barcelona 'being the maritime capital of the Eastern Mediterranean', and its merchants 'holding influence, and establishing colonies' throughout the Mediterranean sea region. Spain is rarely mentioned directly and the Iberian Peninsula generally only referenced to illustrate Catalonia's distinctiveness or cultural superiority (for example, emphasizing the 'best' example of a particular form of material culture). The narrative also stresses the cultural inclusivity of Catalan culture and its long, socially progressive history. Many of the centres highlight 1714 as the end of this period of autonomous evolution, prior to Catalan culture reasserting itself in the nineteenth century, in parallel to the growing economic and industrial success of the region. Oppression and repression of the Catalan people is vividly interpreted at many sites, possibly most noticeably at the Montjuïc castle, an extensive eighteenth-century fortification that stands on the southern hills overlooking Barcelona and its port.

\section{Portraying distinctiveness}

One of the central tenets of Catalan nationalism is the concept that Catalonia has always been culturally distinct from the rest of Spain. Nationalist discourse refers repeatedly to the antiquity of the peoples of the region and its cultural separateness (Gracia Alonso 2013). While the Archaeology Museum of Catalonia does not overtly promote the nationalist agenda, many of the core exhibits denote the prehistoric Iberian Peninsula as occupied by distinct cultural groups. The area of modern Catalonia is graphically shown as an area with its own separate cultural and 'ethnic' groupings during the late Bronze Age, and one that extended into parts of southern France. A display section refers to the 'distinctive custom of the Catalan Iberians' of displaying severed human skulls and weapons at the entrances to major settlements. One gallery is devoted to displaying material associated with this Iberian culture, the name assigned to the groups who lived across the peninsula during the Bronze Age, prior to the arrival of the Greeks and Romans. The introductory panel explains that Greek and Roman writers 'described the Iberians as one people, separate from the Celts'. However, the interpretative panel goes on to claim that 'differences between the Iberian geographic areas of Catalonia and also the east of the peninsula and Andalusia are fairly marked. These individual traits are seen in several aspects: urban planning, systems of writing, and social and political organisation. Conversely, a sense of belonging to the same family, can be seen in things like ceramics and architectural techniques'. A second panel states that around 2500 years ago the Iberians may 'seem to be one single family, but in fact their civilisation was neither uniform nor homogeneous'. The assignation of ethnic labelling on past groups on the basis of ceramic or architectural difference is problematic, and is often more correctly associated with the means by which groups constructed their own identities and how they wished to be perceived (Jones 
2002). This was often based more on political and social negotiations of their landscape and place rather than being markers of ethnic difference.

However, while the interpretation of past Catalan material culture is supported by a school of archaeological thought in the region, the interpretation of material within the Museum of History of Catalonia presents a far more overt nationalistic perspective (Hernández Cardona 1996), and offers what is often a problematic interpretation of the past (Crameri 2006). The museum's founding principles and mission statements are quite clear that one of its primary functions is to express national identity and to serve as a national museum in line with other nations. The original 1996 decree establishing the Museum of History stated that its mission is 'to conserve, exhibit and make known the history of Catalonia as a collective heritage and to strengthen the Citizens' sense of identification with the history of the nation'. It further defines its role as to conserve collective memory, and act as a mirror and symbol of contemporary Catalonia', both across the broader region and on a global basis. Starting with the earliest evidence of human occupation in the region, the inference is that the finding of Homo Erectus skeletal material in Roussillon, and dating to 450,000 BP, somehow represents the earliest Catalan populations. ${ }^{3}$

This emphasis continues to be explored throughout the interpretation of the historic period, where Catalonia's links with the wider Mediterranean are accentuated. The visitor is informed that Catalans are descended from a mix of Greco-Roman and Germanic immigrants and settlers from the Pyrenees: the links to the north and Occitania are emphasised over the rest of the Iberian Peninsula for the next few centuries. Islamic culture is celebrated and is noted for adding to this diversity and distinctiveness. The interpretative displays state that Muslims brought with them innovations in agriculture, culture and philosophical thinking that 'had a decisive influence on the developing Catalan culture' and which Catalans mediated to the rest of Europe. The Islamic period is also used to illustrate the progressive origins of Catalan culture, 'a multi-ethnic and plural society', when Christian Catalans, Moors/Saracens and Jews were all socially integrated. Displays entitled 'The Birth of a Nation' reaffirm that it is in this crucible that Catalan culture was forged, with the shelter of the Carolingian empire allowing for Catalan language to emerge in concert with the first usage of Catalonia to determine a distinct region. Maps throughout the galleries illustrate Catalonia's position with various maritime Mediterranean empires but the most impressive maps and largest wall space is given to Catalonia's own empire. Compared to the vast Mediterranean, the Iberian Peninsula is diminutive. Barcelona is presented as the effective capital of the western Mediterranean in an exhibit pointedly entitled 'Our Sea'. This continues to be viewed as a golden period by Catalan nationalists, when the region was united under the Crown of Aragon (Gracia Alonso 2013). Through focussing on architectural achievements, especially schools of Catalan distinctiveness, literature, scientists, doctors, philosophers and musicians, the specialness of Catalan language, culture and intellect is made paramount. While the increasing marginalization of Jews and Saracens in the Middle Ages is not overlooked, this is often placed in the context of periods of outside repression, when Catalan culture and language was also oppressed. This was also the first period of political and social resistance and some of the most expressive exhibits are given over to peasants' revolts. As the gallery moves forward to 1714, references to the attempts of foreign powers to repress Catalan language and culture, such as under Hapsburg rule, are increasingly accentuated, as is Catalan resistance. New archaeological displays at other museums across Barcelona, such as the Museum of the History of Barcelona, have adopted the same interpretation strategy, sharing a design style and narrative, but also demonstrating an increasingly uniform message: that Catalonia has always been Mediterranean-focussed and that it is both distinctive and contains some of the best archaeology and heritage in the Iberian Peninsula.

In 1714, King Philip V of Bourbon in Madrid imposed a unifying administration across Spain, following the defeat of Aragon. The medieval institutions and liberties of the former Iberian kingdoms, including Catalonia, were now abolished. With the absorption of Catalonia into Spain and repressive strategies to stamp out the use of Catalan language, laws and traditions, the museum narrative shifts away from maps, culture and the Mediterranean and instead concentrates on the contribution of Catalans to industry, science and intellectualism on a world stage. The narrative continues to develop the theme of socially progressive thinking, 
presenting Catalonia's broad support for liberalism in the face of the Carlist and absolutist movements. This was then fertile ground that provided a basis for later democratic and labour movements as well as a resurgence of Catalan culture, despite bourgeois support for social and political conservatism in both Catalonia and the rest of Spain. Particular emphasis is given to the short-lived presidency of Lluís Companys I Jover, with emotive displays relating to his speeches, imprisonment and death. The galleries' response to the reign and policies of Franco is to celebrate the continued resistance and vitality of Catalan culture up until the present day.

\section{Oppression and Resistance}

This concept of resistance, linked to repeated historic oppression by the Spanish state, is a central recurring theme in many of the museums and heritage centres, and features in many of the city's monuments. While the historical veracity around such perspectives will always be contested, these concepts appear repeatedly in the resistance narratives of nationalism. The identification of these themes is then part of authors' interpretative frameworks, rather than being presented as a definitive historical truth. Montjuïc Castle has come to represent the strongest physical manifestation of this perceived oppression. Originally built in the seventeenth century, the fortification was extensively refurbished in the eighteenth century as a military garrison and strategic artillery location. The fortification, visible from most areas of Barcelona, was built on top of the hill of Montjuïc, a place used for quarrying during Roman times and later the burial place of the city's Jewish population. Current interpretations of the site focus on its role as a controlling garrison over the city's residents after 1714. According to the short visitor brochure, published by Barcelona City Council, during industrialization in the nineteenth century it became the symbol of 'an absolutist and militarised state' and during a number of protests against state taxation policy the city was bombed from the site. During the early twentieth century the castle was used for 'imprisonment, torture, trials and executions' as part of the state's repression of 'anarchist terrorism, social uprising and political opposition'. Today the fortification is a major tourist attraction and is maintained as a monument primarily to the repeated historic injustices perceived to have been committed on Catalonia by Spain. Exhibits largely focus on the castle's role in oppression while emotive multimedia exhibits show the bombing of Barcelona from the site. One section of an exhibition gallery within the inner courtyard of the castle is entitled 'Defence and Repression of Barcelona'. The introductory panel states that the 'Repression of Barcelona began after the War of Spanish Succession when the defence of the Bourbon authority... prioritized military control and the subjugation of the population... The repression was indiscriminate and public freedoms were violated from the castle'.

One interesting element of the site is the increased emphasis being placed on its association with Lluís Companys, to the extent that it is almost becoming a martyr's shrine. Lluís Companys i Jover was elected as President of the Generalitat, or regional government of Catalonia, by the Catalan Parliament in 1933. A year later he led a popular uprising and declared the Catalan State within the Spanish Federal Republic, an act for which he was arrested and imprisoned (Bonamusa 2006). Exiled in 1939 to France, the Vichy government extradited him back to Spain where he was later executed at Montjuïc on 15 October 1940. He was interred in Montjuïc Cemetery and a monument has been erected in the castle's moat at the spot where he was executed. A very large Catalan flag, flying to his memory, has been erected on the Bastion of Santa Amalia overlooking the city to the north. An interpretative panel in the castle's visitor centre states that while 'the later governments of France and Germany apologised for collaborating in the arrest and deportation of the President of the Generalitat, the Spanish government has still not declared [his] trial null and void'.

\section{El Born}

Elsewhere a new public centre was officially opened in September 2013 amid heightened calls for Catalan independence from Spain. The El Born Cultural Centre, established in a former market site, has as its central attraction an exposed archaeological excavation (Fig. 1). The interpretive framework around the site has been re-imagined and presented to communicate the horrors of war inflicted on the citizens of Barcelona following the War of Succession in 1714. 
Narratives that emphasise the historical degradation of Catalan political or cultural identity and that reaffirm the distinct and separate nature of Catalan nationalism are presented on a series of interpretative boards placed on a raised walkway around the area of the excavation (Breen et al. 2016). El Born's mission statement welcomes visitors at the main entrances: Historia, Patrimoni, Meemòria and Llibertats. A summary of the exhibition explicitly outlines the narrative of oppression: Catalans backed the Austrian claim for the throne when 'faced with the despotic policies of the Bourbons' and 'opened the doors to the repression'; 'the Catalans world view suffered a radical mutation, subjugated by a regime classified by many historians as "military terrorism"'. The extent to which the city was 'mutilated' is illustrated by focussing on the life of the suburb prior to the demolitions. The narrative is very similar to that offered at the Museum of Catalan History; the Catalans are shown to be multicultural, diverse, and progressive. The ruins' interpretation helps accentuate the vibrancy and colour of Catalan life prior to the disaster: they contained public games halls, businesses, ornamental and vegetable gardens, water wheels, fountains, fruit trees, and a diversity of flowers. These were 'neighbourhoods of personal, professional and social activity'; 'a society connected with half the world ... the city folk were well fed and passionate about sweet things'. Other displays reinforce the message that the area was full of colour, ornament, celebration, dancing, music, theatre and gambling. The visitor is invited to contrast this with its loss, demolition and replacement with stark military necessity and oppression.

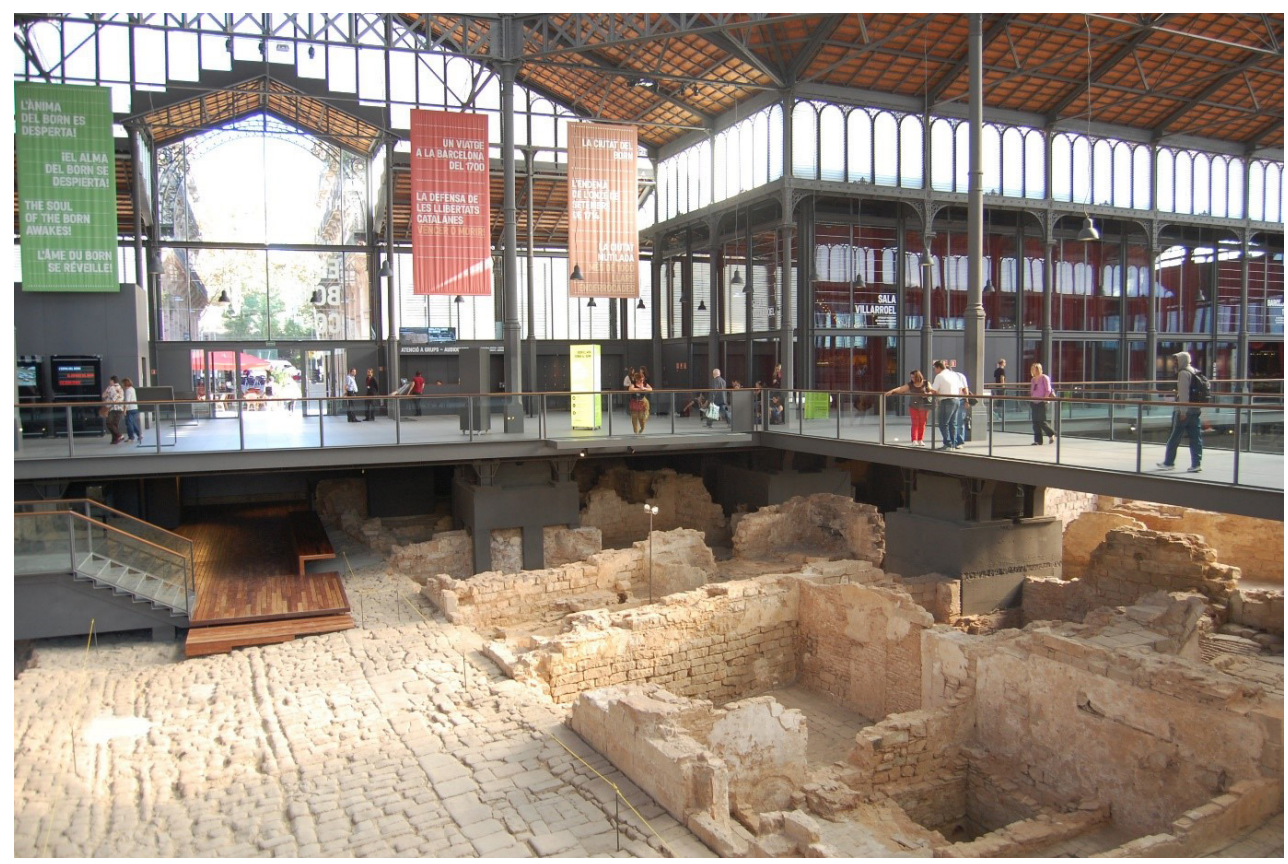

Figure 1. One of the entrances to the El Born Cultural Centre with banners proclaiming that 'The Soul of the Born Awakes', attesting to the cultural reawakening of the Catalan nationalist movement (photo: C. Breen).

Other institutions are similarly engaged in the broader project of both remembering and celebrating the nation. In the 1990s a major refurbishment of the Maritime Museum was undertaken not only to encourage new visitors (Mayolas Créixams 1997), but also to reposition the centrality and importance of past maritime activity within the narratives of Catalan histories. The museum is located within the historic Drassanes Reials (Royal Shipyards), founded in the thirteenth century and described as an example of 'Catalan Gothic civil architecture'. In common with other maritime cultural institutions, themes of shipping, trade, exploration and naval accomplishments are prominent. Accordingly, the permanent exhibition features a mix of vessels, boat models, charts 
and artefacts. Maritime activity of this nature is fundamentally bound up with movement and connecting places and societies, which in itself presents further opportunities for bolstering the nationalist narrative through the internationalization of the Catalans. Indeed, many of the exhibits are concerned with international experiences of maritime life, technological developments and warfare, the centrepiece being the reconstruction of a sixteenth century Royal Galley present at the Battle of Lepanto (1571), which is framed as a Mediterranean struggle between western Christian forces and the Ottoman Empire. Other elements emphasize Catalan experiences and contributions on varying scales, including a reconstruction of Barcelona's waterfront in the fifteenth century, the Creques Catalan Atlas (c.1375), and models of Catalan merchant vessels. In addition, examples of Catalan vernacular craft in the form of fishing llaguts are presented, with attention drawn to their variations, decorative elements and social importance. Catalan vessels with historical associations rather than nautical merit also feature, such as the trawler Joven Ramón, which formed part of the Catalan Coast Guard Fleet during the Civil War. The emphasis within the Catalan components is on economic activity in Barcelona from the Medieval era to the War of Succession, contributions to cartography and exploration, the distinctiveness of Catalan vernacular craft and nineteenth century industrial activity. As a result, the museum echoes themes of identity, the pre-1714 golden age, economic and social vigour and progressiveness witnessed in other more overtly nationalist institutions

\section{Conclusion}

The Catalonian authorities have made clear cultural interpretative choices in adopting a selective and often uncritical set of perspectives on the region's past. These interpretations have been presented in a number of museums and heritage institutions to further develop the concept of a culturally distinct Catalan nation that has been subject to a variety of injustices and periods of oppression perpetrated by the central Spanish state. While many national museums across the globe perform a similar function in the promotion of a national discourse, this study was primarily interested in the Catalan case as it is not recognised as a nation state. The efforts to promote a 'nation' narrative is then compelling in the context of the complex separatism issues across the region. Targeting various audiences, but primarily aimed at the Catalan population, these regional government-supported institutions focus on four key historical periods. In the first instance there is significant emphasis placed on the development of Barcelona during the Roman period, with a view to highlighting the city's seemingly illustrious classical past and thus positioning it within the other great European cities of antiquity. The second main period interpreted and celebrated is the region's medieval heritage, a period that contemporary Catalan nationalists view as a golden period of Catalonia, celebrating its maritime and mercantile reach and the kingdom's perceived independence. Thirdly, the fall of the city in 1714 receives extensive attention and is viewed as the end of an independent Catalonia and the re-emergence of the region's oppression by a central Spanish state. Conversely, the industrialization of the region in the nineteenth century is extensively covered within the museums and is shown in the context of an emergent and successful Catalonia reasserting itself both socially and economically on the European stage.

As with so many nation-building projects, cultural heritage is then being used as an intrinsic part of the socio-political construction of a Catalan state. Through a network of officially supported and funded museums, heritage centres and monumentality, successive nationalist movements within the region have propagated a particular view of the past and shaped it around the separatist agenda. The strategic opening of centres such as El Born by the Generalitat, the regional government of Catalonia, and its subsequent interpretative framework, was clearly designed to build on the separatist momentum. Similarly, Generalitat-funded exhibitions around Civil War themes at Montjuïc Castle appear designed to foster pro-Catalan sentiment, with a recurring theme of oppression. Heritage is then being used to legitimize the political aspirations of the independence movement, through a socially constructed and mediated set of narratives presented in these centres, and presented as the official view of the past.

Received: 14 August 2019 Finally accepted: 26 March 2020 


\section{Notes}

1 J.M. Lanzarote Guiral, 'National Museums in Spain: A History of Crown, Church and People', in A. Aronsson and A. Gabriella Elgenius (eds) Building National Museums in Europe 1750-2010, EuNaMus Report No. 1, Linköping University, Electronic Press, 2011. http://www.ep.liu.se/ecp home/index.en.aspx?issue=064, accessed June 2019.

2 President of the government of Catalonia from 1931-33.

3 Lanzarote Guiral, 'National Museums in Spain'.

\section{References}

Anderson, B. (1983) Imagined Communities: The Origins and Spread of Nationalism, London: Verso.

Bonamusa, F. (2006) 'Lluís Companys i Jover', República i Republicanisme, 2 1-8.

Borgen, C.J. (2010) 'From Kosovo to Catalonia: Separatism and Integration in Europe', Goettingen Journal of International Law 2 (3) 997-1033.

Breen, C., McDowell, S., Reid, G. and Forsythe, W. (2016) 'Heritage and Separatism in Barcelona: The Case of El Born Cultural Centre', International Journal of Heritage Studies 22 (6) 434-45.

Conversi, D. (2000) The Basques, the Catalans, and Spain: Alternative Routes to Nationalist Mobilisation, Nevada: Hurst.

Crameri, K. (2006) 'Official, Artificial or (Arte) Factual?: The Museu d'Histria de Catalunya', International Journal of Iberian Studies, 19 121-35.

(2011) 'We Need Another Hero': The Construction of Josep Moragues as a Symbol of Independence for Catalonia', National Identities 13 (1) 51-65.

De Lluc Serra, M. and Alcalde, G. (2016) 'Dictatorship and Museums: The Museums of Catalonia (Spain) in the Early Years of the Franco Dictatorship (1939-47)', Museum History Journal, 9 (2) 205-14.

Gant, A.C. (2014) 'The Invention of the Barcelona Gothic Quarter', Journal of Heritage Tourism, 9 (1) 18-34.

Garcia-Fuentes, J. (2015) 'Barcelona's Gothic Quarter: Architecture, Ideology and Politics', in Tino Mager (ed) Architecture RePerformed: The Politics of Reconstruction, 35-54, Farnham: Routledge.

Ganau, J. (2008) 'Reinventing Memories: The Origin and Development of Barcelona's Barri Gòtic, 1880-1950', Journal of Urban History, 34 (5) 795-832.

Gillespie, R. (2015) 'Between Accommodation and Contestation: The Political Evolution of Basque and Catalan Nationalism', Nationalism and Ethnic Politics, 21 (1) 3-23.

Gracia Alonso, F.G. (2013) 'Archaeology and Nationalism: The Development of Archaeology in Catalonia in the Early Twentieth Century', Complutum, 24 (2) 131-44.

Guibernau, M. (1997) 'Images of Catalonia', Nations and Nationalism, 3 (1): 89-111. 
Hallal, A.M. (2006) 'Barcelona's Fossar de les Moreres: Disinterring the Heterotopic', Journal of Landscape Architecture, 1 (2) 6-15.

Hastings, A. (1997) The Construction of Nationhood: Ethnicity, Religion and Nationalism, Cambridge: Cambridge University Press.

Hein, H.S. (2014) The Museum in Transition: A Philosophical Perspective, Washington D.C.: Smithsonian.

Hernández Cardona, F.X. (1996) 'Museu d'Història de Catalunya: criteris històrics i museològics', Afers: fulls de recerca i pensament, 11 (23) 367-73.

Hobsbawm, E. and Ranger, T. (1983) The Invention of Tradition, Cambridge: Cambridge University Press.

Holo, S. (1999) Beyond the Prado: Museums and Identity in Democratic Spain, Washington, D.C.: Smithsonian.

Humlebaek, C. (2015) Spain, Inventing the Nation. London: Bloomsbury.

Jones, S. (2002) The Archaeology of Ethnicity: Constructing Identities in the Past and Present, London: Routledge.

Laitin, D.D. (1989) 'Linguistic Revival: Politics and Culture in Catalonia', Comparative Studies in Society and History, 31 (2) 297-317.

Landers, M.W. (2010) 'Catalonia is a Country: World Heritage and Regional Nationalism', Unpublished PhD thesis, University of Oregon.

Mackay, D. (1985) Modern Architecture in Barcelona, Sheffield: The Anglo Catalan Society Occasional Publications.

McLean, F. (1998) 'Museums and the Construction of National Identity: A Review', International Journal of Heritage Studies, 3 (4) 244-52.

Mayolas Créixams, M. (1997) 'Capturing New Publics: The Maritime Museum of Barcelona', Museum International, 49 (1) 12-6.

Monclús, F.J. (2000) 'Barcelona's Planning Strategies: From 'Paris of the South' to the 'Capital of West Mediterranean", GeoJournal, 51 (1-2) 57-63.

Noyes, D. (2003) Fire in the Plaça. Catalan Festival Politics after Franco, Philadelphia: University of Pennsylvania Press, Incorporated.

Orbasli, A. (2002) Tourists in Historic Towns: Urban Conservation and Heritage Management, London: Taylor and Francis Group.

Phillips, M., Woodham, A. and Hooper-Greenhill, E. (2015) 'Foucault and Museum Geographies: A Case Study of the English "Renaissance in the Regions"', Social \& Cultural Geography, 16 (7) 730-63.

Pujol, J. (1979) Construir Catalunya, Barcelona: Generalitat de Catalunya.

Ryan, L., Foote, K.E. and Azaryahu, M. (2016) Narrating Space/Spatializing Narrative: Where Narrative Theory and Geography Meet, Columbus: Ohio State University Press. 
Sánchez-Carretero, C. (2012) 'Hacia una antropología del conflicto aplicada al patrimonio', in B. Santamarina Campos (ed) Geopolíticas patrimoniales. De culturas, naturalezas e inmaterialidades. Una mirada etnográfica, 195-210, Valencia: Germania.

Scorrano, A. (2012) 'Constructing National Identity: National Representations at the Museum of Sydney', Journal of Australian Studies 36 (3) 345-62.

Smith, L. (2015) 'Theorizing Museum and Heritage Visiting', in A. Witcomb and K. Message, The International Handbooks of Museum Studies: Museum Theory, 45984 , Wiley.

Testa, A. (2014) 'Rethinking the Festival: Power and Politics', Method \& Theory in the Study of Religion, 26 (1) 44-73.

Tunbridge, J.E. and Ashworth, G.J. (1996) Dissonant Heritage: The Management of the Past as a Resource in Conflict, Chichester: John Wiley and Sons.

Wright, R. (1985) On Living in an Old Country, Oxford: Oxford University Press.

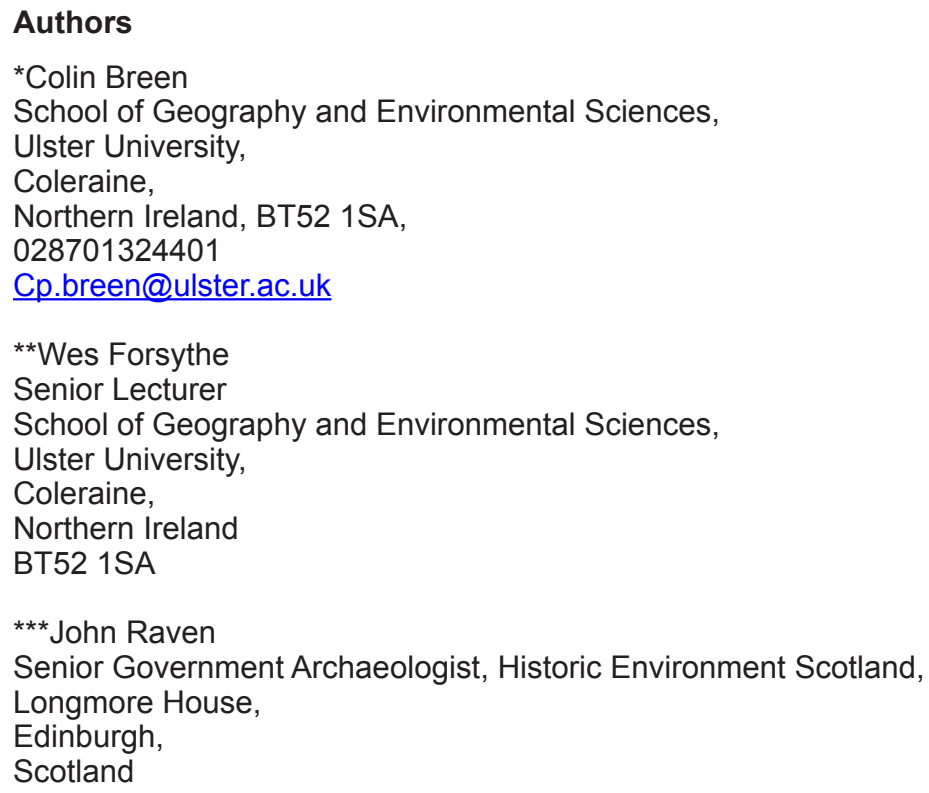

